\title{
Screening of Tomato Cultivars against Fruit Borer, Helicoverpa armigera (Hubner) Infesting Tomato in Mid-hills of Meghalaya
}

\author{
K. Lalruatsangi ${ }^{1 *}$, M.L. Chatterjee ${ }^{1}$, Huirem Diana Devi ${ }^{2}$ and Sandip Patra ${ }^{3}$ \\ ${ }^{1}$ Central Agricultural University, India \\ ${ }^{2}$ Naini Agricultural Institute, SHUATS, Allahabad, India \\ ${ }^{3}$ Division of Crop Protection, ICAR Research Complex for North East Hill Region, Umiam \\ 793103, Meghalaya, India \\ *Corresponding author
}

\section{A B S T R A C T}

\section{Keywords}

Tomato, Cultivars,

Helicoverpa

armigera,

Screening

Article Info

Accepted:

10 March 2019

Available Online:

10 April 2019
The present investigation entitled "Screening of tomato cultivars against fruit borer, Helicoverpa armigera (Hubner) infesting tomato in Mid-hills of Meghalaya" was carried out at the Entomology Research Farm, ICAR Research Complex for NEH Region, Umiam, Meghalaya during 2015 and 2016. Eleven tomato cultivars were screened against fruit borer, H.armigera infesting tomato. The maximum $(39.25 \%$ and $37.00 \%)$ mean percent fruit infestation was recorded on cultivar Badshah during both the years i.e. 2015 and 2016, while minimum (19.50\% and $19.00 \%)$ mean percent fruit infestation was recorded on cultivar Selection-2 and MT-2 during the year 2015 and 2016 respectively. None of the cultivars was found to be free from the infestation of fruit borer. It was further revealed that Selection-2 and MT-2 were found to be better cultivar against $H$. armigera infesting tomato.

\section{Introduction}

Tomato, Lycopersicon esculentum (Miller) is a popular vegetable for its outstanding antioxidant content. It is one of the most important "protective foods" because of its special nutritive value as the pulp and juice are digestible, mild aperients, promoter of gastric secretion and blood purifier. In India, tomato is cultivated in an area of 882 thousand ha with an average annual production of 18736 thousand tonnes and productivity of $21.2 \mathrm{t} \mathrm{ha}^{-1}$ during 2013- 14 (National Horticulture Board, 2015).
Meghalaya is known for production of good quality vegetables among north eastern states (Kumar and Badal, 2004). However, the productivity of tomato is low due to several reasons; the main being the damage caused by insect pests and diseases. Tomato is more prone to insect pests and diseases mainly due to its tenderness and softness as compared to other crops. It is devastated by an array of pests like jassids, aphids, tobacco caterpillar, leaf miner, flea beetles, spider mites, and fruit borer (Katroju et al., 2014). Among these insect pests, fruit borer cause considerable damage to the crop. Tomato fruit borer, 
Helicoverpa armigera Hübner is a polyphagous pest with host range of over 360 plant species including cultivated crops of economic importance (Duraimurugan and Regupathy, 2005). It alone causes the loss in tomato yield to the tune of 50 to 80 per cent (Tewari and Krishnamoorthy, 1984). The monetary loss due to this pest in India has been estimated over one thousand crore rupees per year (Jayraj et al., 1994) and yield loss ranged from 14-100 per cent in different crops. The extent of damage to crop and the consequent loss in yield due to this pest vary considerably amongst crops, regions and locations, and seasons (Fitt, 1989; Wakil et al., 2010). To control the insect pests and to save the crop, pesticides are being used in large quantities. But the continuous and excessive use of these has led to problems of residues in foodstuff and other environmental contamination. Reducing the chances of chemical residues that may remain in the crop due to excessive use of insecticide by growing pest resistant cultivars which are effective and environmentally safe component of IPM programme should be given importance. Host resistance is one of the components in any pest management programme which is economical and safest method for pest management. Hence, development of resistant varieties and their incorporation in IPM schedule is a viable alternative for management of this pest. Keeping the above view in mind, the collected tomato genotypes were screened for their resistance/ susceptibility against the fruit borer.

\section{Materials and Methods}

To study the response of some promising tomato cultivars against H.armigera a field experiment was conducted at Entomology Experimental field of Indian Council of Agricultural Research (ICAR) Complex for NEH Region, Umiam, Meghalaya during 2015-2016. For this experiment eleven tomato varieties/cultivars were used which were obtained from ICAR-RC for NEH Region, Meghalaya.

\section{Varietal screening}

Seeds of eleven varieties, namely, Megha Tomato-2 (MT-2), Megha Tomato-3 (MT-3), H-86, VL-Tomato-4, Selection-1, Selection-2, Selection-3, Arka Vikash, Mahy Gotya, Badshah and Rocky were sown in first week of January in nursery and seedlings were transplanted 45 days after sowing in the main field. Only healthy seedlings were transplanted. The experiment was replicated three times with plot size of $1 \mathrm{~m} \times 3 \mathrm{~m}$. No plant protection measures were applied in the experimental field. Total fruits and damaged fruits were recorded per plot during harvesting time of each variety. Percent fruit infestation was calculated by the following formula (Wakil et al., 2009). Fruit Infestation Percentage $=\mathrm{B} / \mathrm{A} \times 100$

Where, $\mathrm{A}=$ Total fruits (damaged + undamaged), and $B=$ Damaged fruits

A rating system for fruit damage developed by Kashyap and Verma (1986) was followed for estimating relative resistance/ susceptibility.

\section{Results and Discussion}

For the present study, eleven cultivars of tomato viz. MT-2, MT- 3, H-86, VL-Tomato4, Selection-1, Selection-2, Selection-3, Arka Vikash, Mahy Gotya, Badshah, and Rocky were selected for screening of tomato against major pest of tomato. The data on screening of cultivars against fruit borer infestation on number basis are presented in the table 1 . From the data, it could be seen that none of the cultivars was found to be free from the infestation of fruit borer, $H$. armigera. All the varieties recorded more than 15 percent fruit 
infestation for both the years (2015 and 2016).

During the year 2015, the percentage of of tomato fruit infestation ranged from 39.25 (Badshah) to 19.5 (Selection-2). The result presented in Table 2 revealed that the maximum infestation of fruits was recorded on cultivar Badshah (39.25\%) and it did not show a significant difference with that recorded on Mahy Gotya (34.7\%). Therefore these two genotypes were categorized as susceptible to tomato fruit borer on the basis of fruit infestation. Eight cultivars viz., MT-2, MT- 3, H-86, Vl-Tomato-4, Selection-1, Selection-3, Arka Vikash and Rocky were found to be moderately susceptible to fruit borer infestation with a percent damage of $24.25 \%$, $22.50 \%, 29.70 \%, 29.50 \% 22.00 \%, 24.70 \%$, $28.50 \%$ and $24.00 \%$ respectively. One cultivar viz., Selection-2 was found to be moderately resistant $(19.50 \%)$ as shown in Table 2. During the year 2016, the percentage of tomato fruit infestation ranged from 37.00 (Badshah) to 19.00 (MT-2). The result presented in Table 3 revealed that the maximum infestation of fruits was recorded on cultivar Badshah $(37.00 \%)$ and it did not show a significant difference with that recorded on $\mathrm{H}-86$ (31.40\%), VLTomato-4 (33.60\%), Arka Vikash (31.40\%), Mahy Gotya (33.30\%) and Badshah (37.00\%). Therefore these two genotypes were categorized as susceptible to tomato fruit borer on the basis of fruit infestation. Five cultivars viz. MT- 3, Selection-1, Selection-2, Selection-3 and Rocky were found to be moderately susceptible to fruit borer infestation with a percent damage of $23.50 \%, 21.50 \%, 20.80 \%$, $27.00 \%$ and $21.50 \%$ respectively. MT- 2 $(19.00 \%)$ was found to be moderately resistant as shown in Table 3.

Table.1

\begin{tabular}{|l|l|l|}
\hline Sl. & Damage level & Rating \\
\hline No. & & \\
\hline 1. & No damage & Highly Resistant \\
\hline 2. & $0-10.0$ per cent fruit damage & Resistant \\
\hline 3. & $10.1-20.0$ per cent fruit damage & Moderately Resistant \\
\hline 4. & $20.1-30.0$ per cent fruit damage & Moderately Susceptible \\
\hline 5. & $30.1-40.0$ per cent fruit damage & Susceptible \\
\hline 6. & 10.1 per cent fruit damage and above & Highly Susceptible \\
\hline & & \\
\hline
\end{tabular}


Table.2 Screening of tomato germplasm/varieties against major pests of tomato (2015)

\begin{tabular}{|c|c|c|c|}
\hline Sl. & Genotype/ Varieties & Percent damage (Mean of 5 & Index of infestation (Reaction to \\
\hline No. & & pickings) & borer) \\
\hline 1. & MT-2 & 24.25 & Moderate susceptible \\
\hline 2. & MT-3 & 22.50 & Moderate susceptible \\
\hline 3. & $\mathrm{H}-86$ & $\begin{array}{r}29.7 \\
0\end{array}$ & Moderate susceptible \\
\hline 4. & VL-Tomato-4 & $\begin{array}{r}29.5 \\
0\end{array}$ & Moderate susceptible \\
\hline 5. & Selection-1 & $\begin{array}{r}22.0 \\
0\end{array}$ & Moderate susceptible \\
\hline 6. & Selection-2 & $\begin{array}{r}19.5 \\
0\end{array}$ & Moderate resistant \\
\hline 7. & Selection-3 & $\begin{array}{r}24.7 \\
0\end{array}$ & Moderate susceptible \\
\hline 8. & Arka Vikash & $\begin{array}{r}28.5 \\
0\end{array}$ & Moderate susceptible \\
\hline 9. & Mahy Gotya & $\begin{array}{r}34.7 \\
0\end{array}$ & Susceptible \\
\hline 10. & Badshah & $\begin{array}{r}39.2 \\
5\end{array}$ & Susceptible \\
\hline 11. & Rocky & $\begin{array}{r}24.0 \\
0\end{array}$ & Moderate susceptible \\
\hline
\end{tabular}


Table.3 Screening of tomato germplasm/varieties against major pests of tomato (2016)

\begin{tabular}{|l|l|l|l|}
\hline Sl. & Genotype/ Varieties & Percent damage (Mean of & Index of infestation (Reaction to \\
\hline No. & & 5 pickings) & borer) \\
\hline 1. & MT-2 & 19.00 & Moderate resistant \\
\hline 2. & MT-3 & 23.50 & Moderate susceptible \\
\hline 3. & H-86 & 31.40 & Susceptible \\
\hline 4. & VL-Tomato-4 & 33.60 & Susceptible \\
\hline 5. & Selection-1 & 21.50 & Moderate susceptible \\
\hline 6. & Selection-2 & 20.80 & Moderate susceptible \\
\hline 7. & Selection-3 & 27.00 & Moderate susceptible \\
\hline 8. & Arka Vikash & 31.40 & Susceptible \\
\hline 9. & Mahy Gotya & 33.30 & \\
\hline 10. & Badshah & 37.00 & Susceptible \\
\hline 11. & Rocky & 21.50 & Susceptible \\
\hline & & & Moderate susceptible \\
\hline
\end{tabular}

The results obtained during the investigation showed wide variation among different varieties for their resistance to fruit borer, $H$. armigera infesting tomato. The result revealed that none of the cultivars were highly resistant. The result of the present study is similar to the findings of Singh et al., (2013) who worked on field screening of certain tomato varieties for their resistant reaction against Helicoverpa armigera (Hubner) in Manipur valley, India and they reported that none of the varieties were found to be highly resistant. Kashyap and Verma (1986) recorded 42 to 55 per cent damage of tomato fruits in susceptible varieties. Lal et al., (1999) noticed that all the varieties revealed more than five percent fruit infestation and maximum fruit damage recorded was 40.71 percent.
During the present investigation eleven tomato cultivars were screened against fruit borer, H.armigera. The maximum $(39.25 \%$ and $37.00 \%$ ) mean percent fruit infestation was recorded on cultivar Badshah during both the years i.e. 2015 and 2016, while minimum $(19.50 \%$ and $19.00 \%)$ mean percent fruit infestation was recorded on cultivar Selection-2 and MT-2 during the year 2015 and 2016 respectively. None of the cultivars was found to be free from the infestation of fruit borer, $H$. armigera. From the present investigation it can be concluded that the cultivar Selection-2 and MT-2 were found to be better cultivar against $H$. armigera infesting tomato. 


\section{Acknowledgement}

The authors are thankful to the Director, ICAR-Research Complex for NEH Region, Umiam, Meghalaya for providing necessary facilities to conduct this study.

\section{References}

Duraimurugan, P and Regupathy A (2005) Synthetic pyrethroid resistance in field strains of Helicoverpa armigera (Hübner) (Lepidoptera: Noctuidae) in Tamil Nadu, South India. American Journal of Applied Sciences 2: 11461149.

Fitt, G.P (1989) The ecology of Heliothis species in relation to agro ecosystems. Annual Review of Entomology 34: 17-52.

Jayraj, S, Ananthakrishana TM and Veeresh GK (1994) Biological Pest Control in India: Progress and Perspective. RGICS Project No2 Rajiv Gandhi Institute of Contemporary Studies, New Delhi. P. 101.

Kashyap, R.K., and Verma, A.N. (1986). Screening of tomato genotypes for susceptibility to fruit borer, Heliothis armigera (Hubner). Indian Journal of Entomology 48(1): 46-53.

Katroju, RK, Cherukuri SR, Vemuri SB and Reddy N (2014) Bioefficacy of insecticides against fruit borer (Helicoverpa armigera) in tomato (Lycopersicon esculentum). International Journal of Applied Biology and Pharmaceutical Technology 5: 239-243.
Kumar, P and Badal PS (2004) Growth and instability of horticultural crops in North Eastern India. Agricultural Situation in India 61: 499-504.

Lal, SD, Singh SS, Srivastava PM and Phogat KPS(1999). Screening of tomato hybrids for resistance against fruit borer, Helicoverpa armigera (Hubner) in Kumaon hills. Indian Journal of Entomology 61(1): 48-50.

NHB, (2015) Indian Horticulture Database2014. National Horticulture Board, Ministry of Agriculture, Government of India.

Singh, M.S., Baruah, B.K., and Singh, K.I. (2013). Field screening of certain tomato varieties for their resistant reaction against Helicoverpa armigera (Hubner) in Manipur valley, India. Clarion, 2(1): 56-58.

Tewari, GC and Krishnamoorthy PN (1984) Yield loss in tomato caused by fruit borer. Indian Journal of Agricultural Sciences 54: 341-343.

Wakil, W, Ashfaq M, Ghazanfar MU, Afzal $M$ and Riasat $T$ (2009) Integrated management of Helicoverpa armigera in chickpea in rainfed areas of Punjab, Pakistan. Phytoparasitica 37: 415420.

Wakil, W, Ghazanfar MU, Kwon YJ, Qayyum MA and Nasir F (2010) Distribution of Helicoverpa armigera Hubner (Lepidoptera: Noctuidae) in tomato fields and its relationship to weather factors. Entomological Research 40: 290-297.

\section{How to cite this article:}

Lalruatsangi, K., M.L. Chatterjee, Huirem Diana Devi and Sandip Patra. 2019. Screening of Tomato Cultivars against Fruit Borer, Helicoverpa armigera (Hubner) Infesting Tomato in Mid-hills of Meghalaya. Int.J.Curr.Microbiol.App.Sci. 8(04): 1197-1202. doi: https://doi.org/10.20546/ijcmas.2019.804.137 